\title{
Report about Four Novel Mutations in the Prion Protein Gene
}

\author{
Gabi Schelzke $^{a} \quad K^{2}$ atharina Stoeck ${ }^{a}$ Sabina Eigenbrod ${ }^{b}$ \\ Eva Grasbon-FrodI ${ }^{b}$ Lena M. Raddatz ${ }^{a}$ Claudia Ponto ${ }^{a}$ \\ Hans A. Kretzschmar ${ }^{b}$ Inga Zerr ${ }^{a}$ \\ a Department of Neurology, Clinical Dementia Center, Georg August University Goettingen, \\ Goettingen, and bepartment of Neuropathology, Ludwig Maximilian University Munich, \\ Munich, Germany
}

\section{Key Words}

Prion disease · Neurogenetics · Neurology

\begin{abstract}
Background/Aims: Since detection of the prion protein gene (PRNP) more than 30 mutations have been discovered. Some have only been found in single case reports without known intrafamilial accumulation or neuropathological proof so that the causal connection between mutation and disease could not be proved. Those patients often present atypical clinical phenotypes, and it is not unusual that they are classified as diseases other than Creutzfeldt-Jakob disease (CJD). Methods: Cases of suspected CJD have been reported to the national reference center for prion diseases. Clinical and diagnostic data were collected, and a classification of definite, possible or probable prion disease was made. Molecular analysis of PRNP was performed by capillary sequencing. Results: We have described 4 cases with atypical clinical and diagnostic findings and unknown mutations in PRNP so far. Conclusion: Three patients fulfilled the criteria of probable CJD, and 1 patient fulfilled the criteria of possible CJD but the clinical picture in none of the patients was typical CJD; hence, it remained questionable whether the mutations were causal of the disease.

Copyright $(2013$ S. Karger AG, Basel
\end{abstract}

\section{Introduction}

The aggregation of the pathological prion protein $\left(\mathrm{PrP}^{\mathrm{Sc}}\right)$ is the cause of prion diseases like Creutzfeldt-Jakob disease (CJD), fatal familial insomnia (FFI) and Gerstmann-SträusslerScheinker syndrome (GSS), whereby the familial/genetic CJD (gCJD), FFI and GSS are caused 
by an autosomal-dominant mutation in the prion protein gene (PRNP). More than 30 PRNP mutations have been reported so far. Frequent mutations in GCJD are the E200K mutation, which is widespread in Slovakia and in Libyan Jews, the V210I mutation in Italy, furthermore insert mutations in the UK and Germany as well as the E196K mutation in Germany [1-5]. FFI is caused by the $\mathrm{D} 178 \mathrm{~N}$ mutation in combination with methionine at codon 129 of the PRNP [6]. For GSS several mutations exist such as P102L, P105L, A117V, F198S, Q217R, Q212P or D202N [7-13], and the clinical phenotype is typically characterized by a long disease duration and prominent ataxia at onset. In patients with new PRNP mutations, the causal link is substantiated by intrafamilial inheritance of mutations with more than 1 disease-affected patient and/or detection of $\mathrm{PrP}^{\mathrm{Sc}}$ in the brain. In many cases where mutations were reported only in single patients without any positive family history of prion disease or neuropathological examination, the responsibility of the mutation for disease development is likely but remains uncertain. In 4 patients examined here, the genetic testing revealed mutations which have not been reported in the literature before and could not be found in PRNP sequencing series in CJD patients or healthy controls either. The disease phenotypes of these patients are discussed in the paper.

\section{Methods}

Suspected CJD cases in Germany have been reported to the experts of the national reference center for prion diseases in Germany who support the onsite neurologists in the diagnosing process by evaluating and excluding potential differential diagnoses. CSF analyses for 14-3-3 protein were performed by Western blot, and tau protein was measured by ELISA as previously reported [14,15]. Standard measurements of CSF like cell count, protein, oligoclonal bands and antibodies against neurotropic viruses as well as polymerase chain reaction (PCR) were made according to standard procedures. Electro-encephalograms (EEGs) were classified by an experienced neurophysiologist after the criteria established by Steinhoff et al. [16] with detection of periodic sharp wave complexes as the typical picture of CJD and MRI results were assessed by an experienced neuroradiologist with regard to hyperintensities in sensitive sequences (diffusion-weighted imaging, fluid-attenuated inversion recovery, T2-weighted imaging) in basal ganglia and/or two cortical areas (temporal, occipital, parietal or insular) $[17,18]$. To assign the results to definite, possible or probable CJD, the diagnostic criteria of 2001 were used [15] as the examined cases were classified before 2009 when a modification was established [17]. Neuropathological analyses were not done. Genetic analyses were performed from blood samples after informed consent. In brief, genomic DNA was extracted and the coding region of $P R N P$ was amplified by PCR. Subsequently, the complete open reading frame of $P R N P$ was subjected to mutational screening by direct sequencing on an ABI 3130 Genetic Analyzer. The amino acid at codon 129 in coupling with the mutation was determined by cloning as described. A revision of the literature (PubMed search) was performed. All patients/next of kin gave their informed consent prior to publishing the data and present images. All human studies have been approved by the ethics committee of the Georg August University in Goettingen and have been performed in accordance with the ethical standards laid down in the 1964 Declaration of Helsinki.

\section{Results}

\section{Case 1 - Q52P}

The first symptom of this 80 -year-old female patient was a commotio cerebri because of collapse 7 years before the differential diagnosis of CJD was considered and caused by a trend toward epileptic seizures in the EEG, so the diagnosis of symptomatic epilepsy was made. The patient was placed on valproate treatment. In addition the diagnosis of polymyalgia was made because she suffered from pain in the shoulder, weight loss, visual disturbances, a high red blood cell sedimentation rate and an elevated rheumatoid factor. Five months later she 

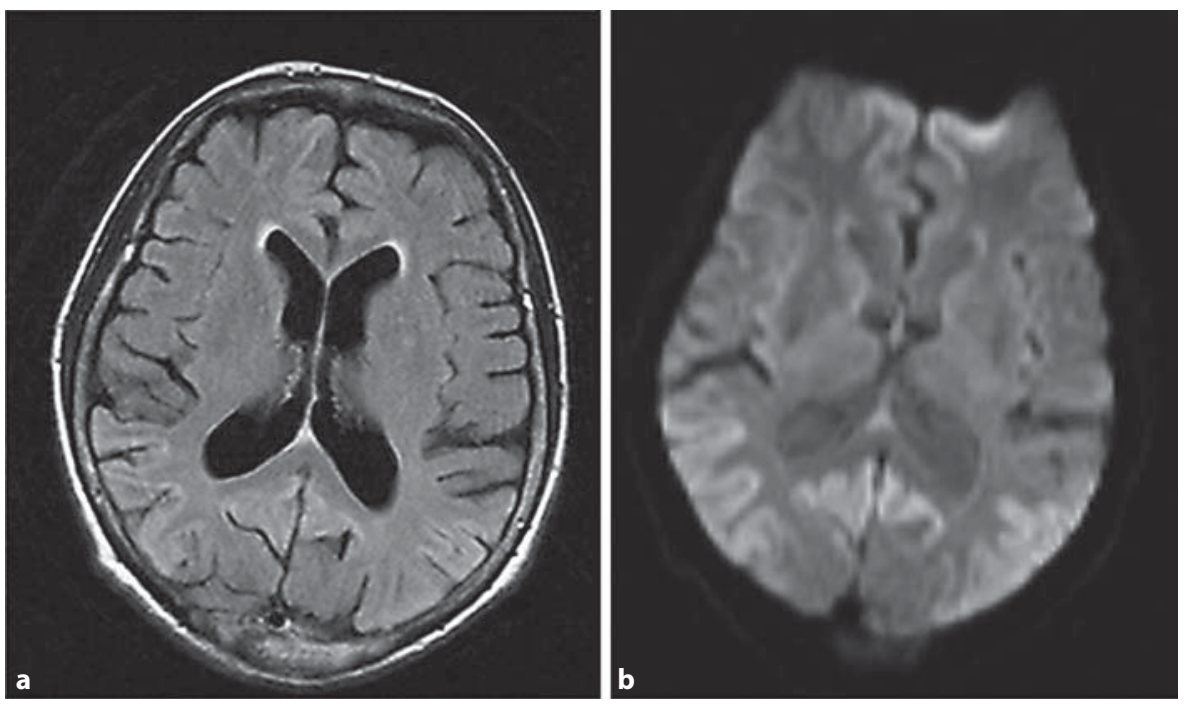

Fig. 1. MRI of the patient in case 2. a Fluid-attenuated inversion recovery sequence with cortical hyperintensities occipital on both sides. b Diffusion-weighted imaging sequence presenting cortical hyperintensities in the occipital and cingulate gyrus.

complained of vertigo, fatigue, exhaustion and ataxia, a rapidly progressive dementia, altered sleep-wake pattern and apraxia became evident. During the disease course, she suffered from 3 grand mal epileptic attacks, whereby the physicians diagnosed a valproate encephalopathy and changed the medication to phenobarbital. Under this medication the EEG did not exhibit epileptic changes anymore, but severe changes of general activity were detected. A following EEG recording 1 month after the onset of the neurological syndrome revealed periodic sharp and slow wave complexes suggestive of CJD. Clinically she developed positive primitive reflexes, pyramidal signs, increased muscle tone and tremor. CSF analysis was negative for 14-3-3 protein; tau protein was normal with $277 \mathrm{pg} / \mathrm{ml}$. An MRI scan was not available. Her nutrition was supported by installation of a percutaneous endoscopic gastrostomy. She died 7.5 years after the first episodes of vertigo and 7 years after the onset of ataxia. In her family no remarkable history of dementia or other neurodegenerative dis-eases existed. Direct sequencing of the PRNP open reading frame revealed a Q52P mutation and heterozygosity for methionine and valine at codon 129 . No autopsy was performed, and no other family member underwent genetic testing.

\section{Case 2 - V203G}

A 74-year-old woman was hospitalized for clarification of an uncertain illness with dementia, cerebellar symptoms, apraxia, withdrawal and depression which had begun 6 months before. Because she also had a breast cancer with widespread metastases, weight loss and autonomic dysregulation, she was diagnosed with a paraneoplastic syndrome at that time. Her examination at hospitalization revealed dementia, withdrawal, ataxia, positive primitive reflexes and sensory disturbance. The comprehensive laboratory tests were normal for all values. 14-3-3 protein was detected in the CSF and also an increased tau protein $(6,332$ $\mathrm{pg} / \mathrm{ml}$, reference $<1,300 \mathrm{pg} / \mathrm{ml}$ ). The EEG displayed only general slowing of the basal activity and no episodes of triphasic waves, but the cerebral MRI scan presented cortical hyperintensities in the occipital and temporal region (fig. 1). She was discharged from the hospital with the diagnosis of paraneoplastic disease, but after tumor surgery no clinical improvement took 
place. After 2 months she developed myoclonus and after 12 months she died in the stage of akinetic mutism. Direct sequencing of the PRNP open reading frame revealed a T $>$ G substitution resulting in an amino acid change from valine to glycine at codon 203 PRNP (V203G) and homozygosity for valine at codon 129 . The family history revealed no neurodegenerative disease in the relatives. No autopsy was performed, and no other relative underwent genetic testing.

\section{Case 3 - Q212H}

The first symptom of the 63-year-old female patient was a visual disorder. She repeatedly requested new glasses (4 times in 1 year) and also complained about diplopia, headache, weakness and coordination disturbance and slight memory deficits. Through the following months she developed developmental delay and ataxia. An MRI scan revealed a tumor in the medial sphenoid wing which was removed, and the histopathological analysis revealed a pituitary adenoma (prolactinoma). The neurological status a few days prior to surgery showed visual disturbances, extrapyramidal signs, hypesthesia, dysdiadochokinesia and global aphasia. Furthermore she was unable to walk. After surgery she developed a diabetes insipidus, which was treated successfully. On discharge she still presented with global aphasia (improved in comparison to the status before surgery), disorientation, concentration and attention disturbances, apraxia, pyramidal and extrapyramidal signs and incontinence, but her gait improved. In the next month she underwent intensive rehabilitation with a transient improvement of gait and orientation. One year later ( 2.5 years after onset of initial symptoms) she was rehospitalized due to a deterioration of her condition. She presented dementia and depression, progressive aphasia, visual disturbances, increased muscle tone apraxia, dystonia of the right arm (alien limb phenomenon), gait disturbances, postural instability and positive pyramidal signs. For the first time the differential diagnosis of a CJD was considered. The CSF analysis for 14-3-3 protein was negative, and tau protein was normal with $76 \mathrm{pg} / \mathrm{ml}$. The EEG presented no triphasic waves and in the MRI scan only the residues of the surgery were seen, no hyperintensities in the cortex or the basal ganglia where detectable. The diagnosis of corticobasal degeneration was made on clinical grounds. In the following 3 months the language production decreased to 1-word sentences, she presented rigidity, gripping reflex, dystonia of both arms and stereotypic movements. A further CSF analysis was again negative for 14-3-3 protein; tau protein increased slightly to $114 \mathrm{pg} / \mathrm{ml}$ (normal value). The EEG presented an epileptic focus and was still negative for CJD-typical findings, also the MRI scan. Blood analysis for a mutation in the $P R N P$ revealed a $\mathrm{G}>\mathrm{C}$ substitution resulting in an amino acid exchange from glutamine to histidine at codon $212(\mathrm{Q} 212 \mathrm{H})$. We also found a silent polymorphism at codon $179(\mathrm{~N} 179 \mathrm{~N})$ and homozygosity for methionine at codon 129. Five years after the first symptoms had occurred, she was akinetic and mute. Two years later she died. No autopsy was performed. The family history was negative for dementia and/or neurodegenerative disorder, and no genetic testing of other family members was performed.

\section{Case $4-N 173 K$}

A decline of a known coronary heart disease was the reason for hospitalizing this 73-year-old male patient. During the hospital stay the physicians suspected a cognitive impairment and the Mini Mental State Examination revealed 17 of 30 points, which corresponds to dementia. Subjective cognitive impairment had occurred 2 years before and he had difficulties to fall asleep and was agitated. Two months later his general condition deteriorated. He suffered from vertigo, multiple falls, ataxia and worsening of the previously described dementia. The patient presented myoclonic jerks so that the neurologist ordered a CSF analysis for 14-3-3 protein which was negative; tau protein was normal with $457 \mathrm{pg} / \mathrm{ml}$, and he featured a slight dysfunction of the blood-brain barrier. The EEG presented a severe distur- 
Fig. 2. Prevalence of genetically transmitted prion disease in humans in the German population. SCJD = Sporadic Creutzfeldt-Jakob disease.

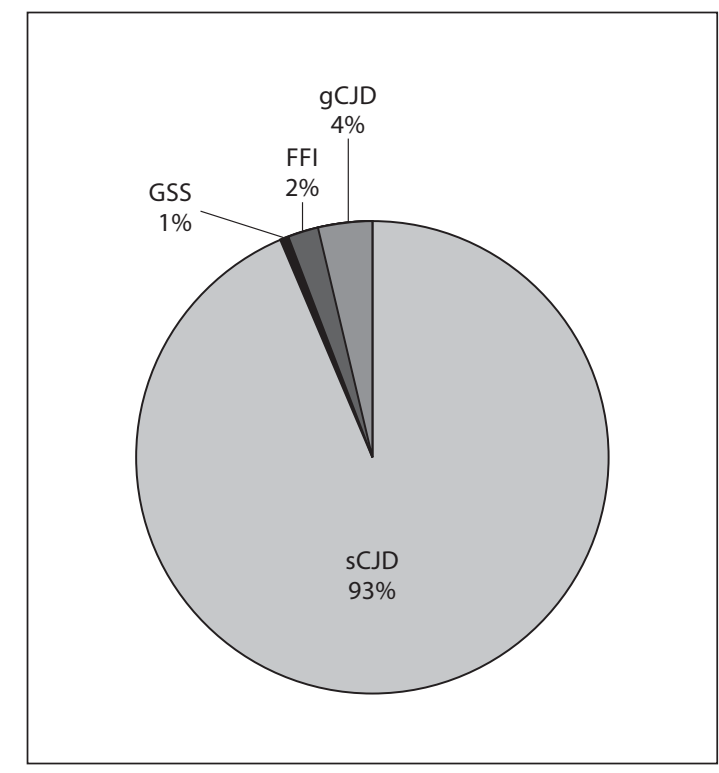

bance of the normal function with some non-periodic triphasic waves. In the MRI scan an arachnoid cyst in the right hemisphere of the cerebellum and some white matter lesions in the cerebrum were detected, but no CJD-typical hyperintensities (fluid-attenuated inversion recovery and T2-weighted images available). Direct sequencing of the PRNP gene open reading frame revealed a $C>G$ substitution at codon 173 resulting in replacement of asparagine by lysine (N173K) and heterozygosity at codon 129 . Cloning experiments demonstrated coupling of the $\mathrm{N} 173 \mathrm{~K}$ mutation with valine. He died 4.6 months after the first hospitalization and 2.5 years after the first symptoms of cognitive decline. He did not undergo an autopsy. No information about the family history was available.

\section{Discussion}

Since starting the CJD surveillance system in Germany, 2,145 patients have undergone a genetic testing [19]. The prevalence of genetic prion diseases in humans in the German population is presented in figure 2. Seven percent of all CJD cases are linked to a mutation and $57 \%$ out of them are gCJD. All cases presented in this paper have not been classified as CJD in the first instance, although cases 1, 3 and 4 fulfilled the criteria of possible CJD and case 2 fulfilled the criteria of a probable CJD. Because of atypical clinical phenotypes only genetic testing led to the assumption that these patients might have been affected by a prion disease. In the absence of neuropathological analysis and genetic testing of relatives the link remains uncertain. Table 1 presents a summary of the patients' data. While the 4 mutations in this study have not been reported in the literature so far, other mutations in a similar region of the PRNP have been observed before. At codon 203 another base exchange with a G-to-A substitution exists with changing valine to isoleucine (V203I). In the literature 2 patients presented this mutation. In 1 patient the V203I mutation in PRNP was combined with homozygosity for methionine [20] and in another case the mutation was combined with heterozygosity at codon 129 PRNP, whereby the mutation was linked to the valine allele [21]. One of these patients underwent an autopsy and CJD could be proven [21]. Another well-known mutation near V203G and V203I on PRNP is the V210I mutation [22]. It occurs worldwide and 
Schelzke et al.: Report about Four Novel Mutations in the Prion Protein Gene

Table 1. Summary of epidemiological data, clinical findings and results of diagnostic tests in the patients described in this paper

\begin{tabular}{|c|c|c|c|c|c|c|c|c|c|c|}
\hline Patient & $\begin{array}{l}\text { Mutation/ } \\
\text { codon } 129\end{array}$ & & $\begin{array}{l}\text { Age } \\
\text { years }\end{array}$ & $\begin{array}{l}\text { Disease } \\
\text { duration } \\
\text { years }\end{array}$ & Clinical findings & $\begin{array}{l}14-3-3 \\
\text { protein }\end{array}$ & $\begin{array}{l}\text { Tau } \\
\text { protein } \\
\mathrm{pg} / \mathrm{ml}\end{array}$ & EEG & MRI & $\begin{array}{l}\text { Accompanying } \\
\text { disease/differential } \\
\text { diagnoses }\end{array}$ \\
\hline 1 & $\begin{array}{l}\text { Q52P; } \\
\text { MV }\end{array}$ & female & 80 & 7.5 & $\begin{array}{l}\text { vertigo, fatigue, exhaustion, } \\
\text { ataxia, dementia, day-night } \\
\text { reversal, apraxia, grand mal } \\
\text { epileptic attacks, paresis right } \\
\text { arm, primitive reflexes, } \\
\text { pyramidal signs, increased } \\
\text { muscle tonus, tremor }\end{array}$ & - & 277 & - & $\varnothing$ & $\begin{array}{l}\text { Epilepsy, } \\
\text { polymyalgia }\end{array}$ \\
\hline 2 & $\begin{array}{l}\text { V203G; } \\
\text { VV }\end{array}$ & female & 74 & 1 & $\begin{array}{l}\text { dementia, apraxia, cerebellar } \\
\text { symptoms, withdrawal, } \\
\text { depression, primitive reflexes, } \\
\text { sensory disturbance, } \\
\text { myoclonus, akinetic mutism }\end{array}$ & + & 6,332 & - & + & breast cancer \\
\hline 3 & $\begin{array}{l}\text { Q212H; } \\
\text { N179N; MM }\end{array}$ & female & 63 & 7 & $\begin{array}{l}\text { visual disorder, diplopia, } \\
\text { headache, weakness, } \\
\text { dementia, developmental } \\
\text { delay, multiple falls, } \\
\text { dystonia, hypesthesia, } \\
\text { dysdiadochokinesia, global } \\
\text { aphasia, hemiparesis, apraxia, } \\
\text { incontinence, dystonia (alien } \\
\text { limb), positive Babinsky sign, } \\
\text { depression, rigor, gripping } \\
\text { reflex, mutism }\end{array}$ & - & 114 & - & - & $\begin{array}{l}\text { prolactinoma, } \\
\text { primary } \\
\text { hyperpara- } \\
\text { thyroidism, } \\
\text { corticobasal } \\
\text { degeneration }\end{array}$ \\
\hline 4 & N173K; MV & male & 73 & 2.5 & $\begin{array}{l}\text { Dementia, vertigo, multiple } \\
\text { falls, ataxia, myoclonus }\end{array}$ & - & 457 & - & - & $\begin{array}{l}\text { Coronary heart } \\
\text { disease, bypass }\end{array}$ \\
\hline
\end{tabular}

- = Negative; + = positive; $\emptyset=$ not available.

is definitely connected to gCJD [23]. The Q212P mutation affects the same codon as the Q212H mutation and effects a substitution of glutamine by proline; hence, this mutation is linked to the GSS syndrome $[13,24]$. Two patients with this mutation have been reported so far. One patient underwent an autopsy and in the neuropathological examination he presented $\mathrm{PrP}^{\mathrm{Sc}}$ deposition in the brain, an abnormal PrP immunoblot and no spongiform degeneration [13]. At codon 173 no other irregularity has been described before, but next to codon 173, at codon 171 , whereby its responsibility for causation of CJD could not be clarified yet. The N171S mutation was reported first in 1997 in a Brazilian family where 6 of 12 tested relatives were positive for the mutation and 5 presented signs of an illness, distributed over 3 generations. The prominent symptoms were different psychiatric features (depression, delusion, hallucination, schizophrenia, schizoaffective disorders). Samaia et al. [25] summarized a new causally linked mutation with a psychiatric featured phenotype. In contradiction Tsai et al. [26] tested a large group of patients $(n=234)$ with familial schizophrenia, non-familial schizophrenia and healthy controls and did not find the N171S mutation in PRNP; nonetheless, an association between the mutation and the disease was not excluded by this analysis. The notion that N171S might be a non-pathogenic polymorphism has been reinforced by the fact 
that it was also found in healthy controls in PRNP screening studies [24, 27]. Appleby et al. [28] described an African-American family with the gCJD D178N-129V mutation in combination with the N171S polymorphism in 3 generations, which presented also prominent psychiatric symptoms. More speculative is a connection between the N173K mutation and the D178N mutation, which are only separated by 5 codons. In clinical appearance, the D178N mutation as well as the $\mathrm{N} 173 \mathrm{~K}$ mutation are accompanied by several sleeping abnormalities. Certainly the patient in case 3 is linked to the allele with valine at codon 129 , whereby sleeping abnormalities in the D178N mutation are generally linked to methionine at codon 129 (lead to FFI) and are not typical of the valine-linked allele (lead to gCJD) [29]. In the literature some more cases have been presented with uncommon mutations in PRNP, atypical clinical course and without neuropathological proof of $\mathrm{PrP}^{\mathrm{Sc}}$ - e.g. the D202G mutation with a disease duration of 16 years [30]. In other cases neuropathological analyses and proof of $\mathrm{PrP}^{\mathrm{Sc}}$ have been detected and the mutations could be linked to prion disease in defiance of atypical clinical phenotype or negative results in diagnostic tests - e.g. the S132I mutation in a 62-year-old woman with a disease duration of 18 months and merely dementia as clinical signs, the G131V mutation in a 51-year-old man with 9 years of dementia and ataxia, the A133V mutation in a 63-year-old woman with prominent progressive supranuclear palsy syndrome, the P105S mutation in a 30-year-old woman with a disease duration of 10 years and symptoms of dementia, aphasia, parkinsonism and behavioural changes, further the R208H mutation in a 61-year-old man with a disease duration of 7 months with dementia, psychiatric symptoms and ataxia [31-35]. Only very few patients with rare mutations presented myoclonic jerks, positive 14-3-3 protein detection in CSF, periodic sharp and slow wave complexes in the EEG or hyperintensities in the MRI scan.

\section{Conclusion}

Mutations in PRNP can produce diverse clinical phenotypes; that is why the patients described in this examination do not necessarily present the typical clinical CJD-syndrome. Moreover, in some cases the final diagnoses are still unexplained, although in patient 4 CJD is the most likely diagnosis and in case 2 no alternative diagnosis was suggested or supported by any diagnostic tests and/or clinical syndrome. The atypical clinical course and the long disease durations were the reasons for requesting a genetic test. Unfortunately no neuropathological analyses are available for the considered patients and also no genetic testing in relatives was performed in order to prove inheritance and intrafamilial accumulation of the mutations. In other cases in the literature, where only single cases with new mutations and atypical clinical courses have been presented, the CJD diagnoses could be proven a few years later by a neuropathological analysis. For instance, the E196K mutation in $P R N P$ was reported the first time by Peoc'h et al. [22] in 2000 and the proof of disease pathogenesis was performed 11 years later with neuropathological verification and presentation of families with more than 1 affected relative [5]. Another example is the T188K mutation, which was reported for the first time in 2000 by Finkh et al. [36], and the neuropathological evidence was provided in 2007 by Roeber et al. [37]. Another way to verify the pathogenic role of such rare mutations could be the genetic testing of a healthy population. The description of the cases mentioned in this report can serve to detect future cases with these mutations in the clinical findings and results of the diagnostic tests, and there are some further examples of the wide spectrum of potential PRNP mutation-mediated diseases. 
Schelzke et al.: Report about Four Novel Mutations in the Prion Protein Gene

\section{Acknowledgement}

This study was funded by the Robert Koch-Institute through funds of the Federal Ministry of Health (grant No. 1369-341) and by a grant from the Federal Ministry of Education and Research from the JPND program (DEMTEST, Biomarker based diagnosis of rapid progressive dementias-optimization of diagnostic protocols, 01ED1201A). The work was supported by a grant from the European Commission: PRIORITY FP7 (grant No. 222887).

\section{Disclosure Statement}

The authors declare that they have no conflict of interest.

\section{References}

1 Mitrova E, Brown P, Hroncova D, Tatara M, Zilák J: Focal accumulation of CJD in Slovakia: retrospective investigation of a new rural familial cluster. Eur J Epidemiol 1991;7:487-489.

- 2 Kovacs GG, Puopolo M, Ladogana A, Pocchiari M, Budka H, van Duijn C, Collins SJ, Boyd A, Giulivi A, Coulthart M, Delasnerie-Laupretre N, Brandel JP, Zerr I, Kretzschmar HA, de Pedro-Cuesta J, Calero-Lara M, Glatzel M, Aguzzi A, Bishop M, Knight R, Belay G, Will R, Mitrova E, EUROCJD: Genetic prion disease: the EUROCJD experience. Hum Genet 2005;118:166-174.

- 3 Ladogana A, Puopolo M, Poleggi, Almonti S, Mellina V, Equestre M, Pocchiari M: High incidence of genetic human transmissible spongiform encephalopathies in Italy. Neurology 2005;64:1592-1597.

- 4 Meiner Z, Gabizon R, Prusiner SB: Familial Creutzfeldt-Jakob disease. Codon 200 prion disease in Libyan Jews. Medicine (Baltimore) 1997;76:227-237.

5 Schelzke G, Eigenbrod S, Romero C, Varges D, Breithaupt M, Taratuto AL, Kretzschmar HA, Zerr I: Genetic prion disease with codon 196 PRNP mutation: clinical and pathological findings. Neurobiol Aging 2011;32:756, e1-9.

6 Gambetti P, Parchi P, Petersen RB, Chen SG, Lugaresi E: Fatal familial insomnia and familial Creutzfeldt-Jakob disease: clinical, pathological and molecular features. Brain Pathol 1995;5:43-51.

- 7 Hsiao K, Baker HF, Crow TJ, Poulter M, Owen F, Terwilliger JD, Westaway D, Ott J, Prusiner SB: Linkage of a prion protein missense variant to Gerstmann-Straussler syndrome. Nature 1989;338:342-345.

8 Kitamoto T, Ohta M, Doh-ura K, Hitoshi S, Terao Y, Tateishi J: Novel missense variants of prion protein in Creutzfeldt-Jakob disease or Gerstmann-Straussler syndrome. Biochem Biophys Res Commun 1993;191:709714.

9 Doh-ura K, Tateishi J, Sasaki H, Kitamoto T, Sakaki Y: Pro-Leu change at position 102 of prion protein is the most common but not the sole mutation related to Gerstmann-Straussler syndrome. Biochem Biophys Res Commun 1989;163:974-979.

10 Hsiao KK, Cass C, Schellenberg G, Bird T, Devine-Gage E, Wisniewski H, Prusiner SB: A prion protein variant in a family with the telencephalic form of Gerstmann-Straussler-Scheinker syndrome. Neurology 1991;41:681684.

11 Hsiao K, Dlouhy SR, Farlow MR, Cass C, Da Costa M, Conneally PM, Hodes ME, Ghetti B, Prusiner SB: Mutant prion proteins in Gerstmann-Straussler-Scheinker disease with neurofibrillary tangles. Nat Genet 1992;1: 68-71.

12 Ghetti B, Tagliavini F, Giaccone G, Bugiani O, Frangione B, Farlow MR, Dlouhy SR: Familial GerstmannStraussler-Scheinker disease with neurofibrillary tangles. Mol Neurobiol 1994;8:41-48.

13 Piccardo P, Dlouhy SR, Lievens PM, Young K, Bird TD, Nochlin D, Dickson DW, Vinters HV, Zimmerman TR, Mackenzie IR, Kish SJ, Ang LC, De Carli C, Pocchiari M, Brown P, Gibbs CJ, Gajdusek DC, Bugiani O, Ironside J, Tagliavini F, Ghetti B: Phenotypic variability of Gerstmann-Straussler-Scheinker disease is associated with prion protein heterogeneity. J Neuropathol Exp Neurol 1998;57:979-988.

14 Sanchez-Juan P, Green A, Ladogana A, Cuadrado-Corrales N, Sáanchez-Valle R, Mitrová E, Stoeck K, Sklaviadis T, Kulczycki J, Hess K, Bodemer M, Slivarichová D, Saiz A, Calero M, Ingrosso L, Knight R, Janssens AC, van Duijn CM, Zerr I: CSF tests in the differential diagnosis of Creutzfeldt-Jakob disease Neurology 2006;67:637-643.

15 Zerr I, Pocchiari M, Collins S, Brandel JP, de Pedro Cuesta J, Knight RS, Bernheimer H, Cardone F, DelasnerieLauprêtre N, Cuadrado Corrales N, Ladogana A, Bodemer M, Fletcher A, Awan T, Ruiz Bremón A, Budka H, Laplanche JL, Will RG, Poser S: Analysis of EEG and CSF 14-3-3 proteins as aids to the diagnosis of CreutzfeldtJakob disease. Neurology 2000;55:811-815.

16 Steinhoff BJ, Zerr I, Glatting M, Schulz-Schaeffer W, Poser S, Kretzschmar HA: Diagnostic value of periodic complexes in Creutzfeldt-Jakob disease. Ann Neurol 2004;56:702-708. 
17 Zerr I, Kallenberg K, Summers DM, Romero C, Taratuto A, Heinemann U, Breithaupt M, Varges D, Meissner B, Ladogana A, Schuur M, Haik S, Collins SJ, Jansen GH, Stokin GB, Pimentel J, Hewer E, Collie D, Smith P, Roberts H, Brandel JP, van Duijn C, Pocchiari M, Begue C, Cras P, Will RG, Sanchez-Juan P: Updated clinical diagnostic criteria for sporadic Creutzfeldt-Jakob disease. Brain 2009;132:2659-2668.

18 Grasbon-Frodl E, Schmalzbauer R, Weber P, Krebs B, Windl O, Zerr I, Kretzschmar HA: A novel three extrarepeat insertion in the prion protein gene (PRNP) in a patient with Creutzfeldt-Jakob disease. Neurogenetics 2004;5:249-250.

19 Windl O, Giese A, Schulz-Schaeffer W, Zerr I, Skworc K, Arendt S, Oberdieck C, Bodemer M, Poser S, Kretzschmar HA: Molecular genetics of human prion diseases in Germany. Hum Genet 1999;105:244-252.

20 Peoc'h K, Guerin C, Brandel JP, Launay JM, Laplanche JL: First report of polymorphisms in the prion-like protein gene (PRND): implications for human prion diseases. Neurosci Lett 2000;286:144-148.

-21 Jeong BH, Jeon YC, Lee YJ, Cho HJ, Park SJ, Chung DI, Kim J, Kim SH, Kim HT, Choi EK, Choi KC, Carp RI, Kim YS: Creutzfeldt-Jakob disease with the V203I mutation and M129V polymorphism of the prion protein gene (PRNP) and a 17 kDa prion protein fragment. Neuropathol Appl Neurobiol 2010;36:558-563.

22 Peoc'h K, Manivet P, Beaudry P, Attane F, Besson G, Hannequin D, Delasnerie-Lauprêtre N, Laplanche JL: Identification of three novel mutations (E196K, V203I, E211Q) in the prion protein gene (PRNP) in inherited prion diseases with Creutzfeldt-Jakob disease phenotype. Hum Mutat 2000;15:482.

23 Pocchiari M, Salvatore M, Cutruzzola F, Genuardi M, Allocatelli CT, Masullo C, Macchi G, Alemá G, Galgani S, Xi YG: A new point mutation of the prion protein gene in Creutzfeldt-Jakob disease. Ann Neurol 1993;34:802-807.

24 Beck JA, Poulter M, Campbell TA, Adamson G, Uphill JB, Guerreiro R, Jackson GS, Stevens JC, Manji H, Collinge J, Mead S: PRNP allelic series from 19 years of prion protein gene sequencing at the MRC Prion Unit. Hum Mutat 2010;31:E1551-1563.

25 Samaia HB, Mari JJ, Vallada HP, Moura RP, Simpson AJ, Brentani RR: A prion-linked psychiatric disorder. Nature 1997;390:241.

26 Tsai MT, Su YC, Chen YH, Chen CH: Lack of evidence to support the association of the human prion gene with schizophrenia. Mol Psychiatry 2001;6:74-78.

-27 Mead S, Stumpf MP, Whitfield J, Beck JA, Poulter M, Campbell T, Uphill JB, Goldstein D, Alpers M, Fisher EM, Collinge J: Balancing selection at the prion protein gene consistent with prehistoric kurulike epidemics. Science 2003;300:640-643.

28 Appleby BS, Appleby KK, Hall RC, Wallin MT: D178N, 129Val and N171S, 129Val genotype in a family with Creutzfeldt-Jakob disease. Dement Geriatr Cogn Disord 2010;30:424-431.

-29 Gambetti P: Fatal familial insomnia and familial Creutzfeldt-Jakob disease: a tale of two diseases with the same genetic mutation. Curr Top Microbiol Immunol 1996;207:19-25.

30 Heinemann U, Krasnianski A, Meissner B, Grasbon-Frodl EM, Kretzschmar HA, Zerr I: Novel PRNP mutation in a patient with a slow progressive dementia syndrome. Med Sci Monit 2008;14:CS41-43.

-31 Hilton DA, Head MW, Singh VK, Bishop M, Ironside JW: Familial prion disease with a novel serine to isoleucine mutation at codon 132 of prion protein gene (PRNP). Neuropathol Appl Neurobiol 2009;35:111-115.

32 Panegyres PK, Toufexis K, Kakulas BA, Cernevakova L, Brown P, Ghetti B, Piccardo P, Dlouhy SR: A new PRNP mutation (G131V) associated with Gerstmann-Straussler-Scheinker disease. Arch Neurol 2001;58:18991902.

-33 Rowe DB, Lewis V, Needham M, Rodriguez M, Boyd A, McLean C, Roberts H, Masters CL, Collins SJ: Novel prion protein gene mutation presenting with subacute PSP-like syndrome. Neurology 2007;68:868-870.

-34 Tunnell E, Wollman R, Mallik S, Cortes CJ, Dearmond SJ, Mastrianni JA: A novel PRNP-P105S mutation associated with atypical prion disease and a rare PrPSc conformation. Neurology 2008;71:1431-1438.

-35 Basset-Leobon C, Uro-Coste E, Peoc'h K, Haik S, Sazdovitch V, Rigal M, Andreoletti O, Hauw JJ, Delisle MB: Familial Creutzfeldt-Jakob disease with an R208H-129V haplotype and Kuru plaques. Arch Neurol 2006;63: 449-452.

-36 Finckh U, Müller-Thomsen T, Mann U, Eggers C, Marksteiner J, Meins W, Binetti G, Alberici A, Hock C, Nitsch RM, Gal A: High prevalence of pathogenic mutations in patients with early-onset dementia detected by sequence analyses of four different genes. Am J Hum Genet 2000;66:110-117.

37 Roeber S, Grasbon-Frodl EM, Windl O, Krebs B, Xiang W, Vollmert C, Illig T, Schröter A, Arzberger T, Weber P, Zerr I, Kretzschmar HA: Evidence for a pathogenic role of different mutations at codon 188 of PRNP. PLoS One 2005;14;3:e2147. 